\title{
Study of pathologies on flexible floors in the city of Teófilo Otoni, Minas Gerais
}

\section{State, Brazil}

Estudo de patologias em pavimentos flexíveis na cidade de Teófilo Otoni, estadlo de Minas Gerais, Brasil

Estudio de patologías en pisos flexibles en la ciudad de Teófilo Otoni, estado de Minas Gerais, Brasil

Received: 06/07/2021 | Reviewed: 06/13/2021 | Accept: 06/22/2021 | Published: 07/02/2021

Heberson Teixeira da Silva

ORCID: https://orcid.org/0000-0001-9163-6984

Federal University of the Jequitinhonha and Mucuri Valleys, Brazil

E-mail: hebersonteixeirasilva@gmail.com

Luély Souza Guimarães

ORCID: https://orcid.org/0000-0001-8817-7326

Federal University of the Jequitinhonha and Mucuri Valleys, Brazil

E-mail: luelyguimaraes@ hotmail.com

Dilceu Silveira Tolentino Júnior

ORCID: https://orcid.org/0000-0003-2435-7576

Federal University of the Jequitinhonha and Mucuri Valleys, Brazil

E-mail: dilceujunior@bol.com.br

Fernanda Andrade Dutra

ORCID: https://orcid.org/0000-0001-6018-8904

Federal University of the Jequitinhonha and Mucuri Valleys, Brazil

E-mail: fernanda-dutraa@hotmail.com

Lucas Grateki Barbosa

ORCID: https://orcid.org/0000-0001-5635-8771

Federal University of the Jequitinhonha and Mucuri Valleys, Brazil

E-mail: lucas.grateki@hotmail.com

Luan Siqueira Santos

ORCID: https://orcid.org/0000-0003-1080-7476

Federal University of the Jequitinhonha and Mucuri Valleys, Brazil

E-mail: luansiqueiras_@hotmail.com

Alexandre Sylvio Vieira da Costa

ORCID: https://orcid.org/0000-0001-7251-7816

Federal University of the Jequitinhonha and Mucuri Valleys, Brazil

E-mail: alexandre.costa@ufvjm.edu.br

Stênio Cavalier Cabral

ORCID: https://orcid.org/0000-0001-5241-9776

Federal University of the Jequitinhonha and Mucuri Valleys, Brazil

E-mail: stenio.cavalier@ufvjm.edu.br

Lucas Ferreira Freitas

ORCID: https://orcid.org/0000-0001-6826-6970

Federal University of the Jequitinhonha and Mucuri Valleys, Brazil

E-mail: lucas.freitas@ufvjm.edu.br

\begin{abstract}
It is a function of the highways to provide comfort, safety, and good rolling conditions to users. Therefore, the roads must be correctly designed showing adequate quality and durability for use. However, what is observed in Brazil is that most of the existing roads are not in good condition due to the number of pathologies found in them, bringing discomfort and insecurity to users. Bearing in mind that the flexible floor is the most used in the country, it is necessary to study the defects found during its useful life, which may be of structural or functional origin, to offer adequate maintenance and possibly better-rolling conditions to those who travel through it. Thus, the present study tackles pathological problems observed on a flexible pavement in the Municipality of Teófilo Otoni, Brazil, its possible causes, and some proposals for measures to be taken in the construction and maintenance processes to reduce the appearance of these pathologies. In addition, the identification and classification of pathologies and nonconformities found in the studied places were carried out. Thus, there was a need for maintenance so that its
\end{abstract}


functionality is not affected, requiring the use of recovery techniques through resurfacing or a sealing layer, improving drainage and milling, which provides longer life and avoids inconvenience to users.

Keywords: Flexible floor; Pathologies; Restoration.

\section{Resumo}

É função das rodovias proporcionar conforto, segurança e boas condições de rodagem aos usuários. Portanto, as estradas devem ser corretamente projetadas apresentando qualidade e durabilidade adequadas para o uso. Porém, o que se observa no Brasil é que grande parte das estradas existentes não está em bom estado devido ao número de patologias nelas encontradas, trazendo desconforto e insegurança aos usuários. Tendo em vista que o piso flexível é o mais utilizado no país, faz-se necessário o estudo dos defeitos encontrados durante sua vida útil, que podem ser de origem estrutural ou funcional, para oferecer uma manutenção adequada e possivelmente melhores condições de rodagem a quem viajar através dele. Assim, o presente estudo aborda problemas patológicos observados em um pavimento flexível no Município de Teófilo Otoni, Brasil, suas possíveis causas, e algumas propostas de medidas a serem tomadas nos processos de construção e manutenção para reduzir o aparecimento dessas patologias. Além disso, foi realizada a identificação e classificação das patologias e não conformidades encontradas nos locais estudados. Assim, houve a necessidade de manutenção para que sua funcionalidade não fosse afetada, exigindo a utilização de técnicas de recuperação por meio de recapeamento ou camada de selamento, melhorando a drenagem e fresagem, o que proporciona maior vida útil e evita transtornos aos usuários.

Palavras-chave: Pavimento flexível; Patologias; Restauração.

\section{Resumen}

Es función de las carreteras brindar comodidad, seguridad y buenas condiciones de conducción a los usuarios. Por lo tanto, las carreteras deben diseñarse correctamente con la calidad y durabilidad adecuadas para su uso. Sin embargo, lo que se observa en Brasil es que la mayoría de los caminos existentes no se encuentran en buen estado debido a la cantidad de patologías que se encuentran en ellos, trayendo malestar e inseguridad a los usuarios. Teniendo en cuenta que el piso flexible es el más utilizado en el país, es necesario estudiar los defectos encontrados durante su vida útil, los cuales pueden ser de origen estructural o funcional, para ofrecer un adecuado mantenimiento y posiblemente mejores condiciones de funcionamiento para los que la transitan. Así, el presente estudio aborda los problemas patológicos observados sobre un pavimento flexible en el Municipio de Teófilo Otoni, Brasil, sus posibles causas, y algunas propuestas de medidas a tomar en los procesos de construcción y mantenimiento para reducir la aparición de estas patologías. Además, se realizó la identificación y clasificación de patologías y no conformidades encontradas en los lugares estudiados. Así, existía la necesidad de un mantenimiento para que su funcionalidad no se viera afectada, requiriendo el uso de técnicas de recuperación mediante capa de repavimentación o sellado, mejorando el drenaje y el fresado, lo que proporciona una mayor vida útil y evita molestias a los usuarios.

Palabras clave: Suelo flexible; Patologias; Restauración.

\section{Introduction}

Brazil has an extensive territorial area with a road network that is characterized by being composed of federal, state, and municipal highways, being $119,953.5 \mathrm{~km}, 261,562.8 \mathrm{~km}$, and 1,339,126.9 km, respectively, totaling 1,720,643.2 km of highways. Despite the great importance of this modal, it has been observed that investments for the maintenance and construction of this infrastructure are insufficient, resulting in several pathologies (CNT, 2018).

The National Traffic Department (DNIT) states that a highway must provide satisfactory conditions for efficient traffic from a long-term perspective, permanently characterizing satisfactory performance. Thus, the services are preserved, the maintenance of the pavements being essential, as it allows safe and satisfactory traffic, as well as a long life cycle (DNIT, 2006; Marinho, 2021).

The road network must be designed with mechanisms that guarantee good durability, which can contribute to reducing maintenance costs. This durability is associated with three conditions, namely, the elaboration of a good project, which has the specification of the pavement layers according to the conditions of the place and volume of traffic; the satisfactory execution of the works, with adequate monitoring of the quality of services and materials, used, and, finally, the preventive and corrective maintenance of the pavement (Costa, 2019; Batista, 2019).

The monitoring of roads is carried out through the diagnosis of pathologies, characterized as defects that can be constructive or not and are developed over the useful life of the pavement depending on the use, climatic conditions, and 
caused by poor execution. The most common are cracks, holes (also known as pots or pits), cracks (longitudinal or transverse), deformations, disintegration, exudation, in blocks, edges, undermines (Barreto, 2016; Czrnhak, 2019).

Approximately $60 \%$ of the Brazilian road network has some type of pathology, that is, defects that affect both the surface and the lower layers, causing damage to the pavement structure, which can originate from the poor quality of the material and execution of the pavement, intense action of vehicles, inadequate projects, the action of traffic that alters the properties of the materials that make up the pavement, natural phenomena, such as heavy rains and landslides, and others (Reis, 2009; Ribeiro, 2017).

The analysis and study of pathologies seek to determine their causes and origins and, based on this knowledge, it becomes possible to prescribe the appropriate therapy for the problem in question, since if we treat the symptoms without eliminating the cause, it tends to manifest itself again (Alvarez and Rodgher, 2018; Zuchetti, 2015).

Thus, the quality of the road pavements is an essential factor, as it directly impacts financial costs, therefore, it is necessary to have efficiency and quality in the execution of the service and the raw material used, with maintenance being imperative. If periodic conservation measures do not take place, this can cause damage not only to the State but also to users. Thus, road pavements must be of good quality, as this will have a great influence on the performance of road transport and the country's economy, as poor pavement conditions will increase transport costs and reduce comfort and passenger safety (Paixão, 2017).

The research is based on the analysis of pathological problems presented in some places by Teófilo Otoni, on the discussion of possible causes, and on the provision of information that can assist in the study of pathologies in city pavements and in the determination of suitable alternatives for solving the problem.

\subsection{General Concepts in Paving}

The pavement is configured as a superstructure, being a set of layers of finite thickness, carried out after the earthworks, to distribute and support the vertical forces of the vehicle under it, in this way, comfort and safe rolling conditions are improved. and resistant to horizontal stress, which makes the rolling surface more durable (DNIT, 2006; Gomes \& Da Silva, 2018).

Asphalt pavements must obey the requirements, such as the promotion of convenience and the guarantee of ideal traffic conditions, however, when this does not occur, there are the first signs of the appearance of pathologies that generate disorders and reduce the life span. The pathologies are caused by some factors, such as design and/or execution errors, bad weather, lack of maintenance, and others, therefore, a good pavement resists the traffic of vehicles and the climatic conditions in which they are submitted (Rosa et al., 2016).

The anomalies found on the roads are directly related to the types of pavement adopted. In Brazil, the classification is based on rigid, semi-rigid, and flexible floors.

\subsection{Floor types}

The planning of a highway must initially consider some points that will determine its performance. These are based on the analysis of the purpose of the paving (pedestrians, small, medium, or large vehicles), what are the main characteristics of the vehicles that will travel it, what are the possible damages that these can cause to the paving, how to minimize these impacts and others. Thus, with this prior analysis, greater durability and longevity and the lowest possible cost are obtained to guarantee the comfort and safety of those who travel on the highway, aimed at reducing the maintenance of the highway, according to the type of pavement adopted (Daibert, 2015). 
Rigid floors are composed of four layers and can be related to Portland cement concrete, according to figure 1. The Portland cement concrete surface layer is laid on one of granular material or stabilized with cement, and above the subgrade and at the top, a reinforcement of the subgrade when necessary (Bernucci et al., 2008; Da Silva, 2019).

Figure 1. Rigid type pavement structure.

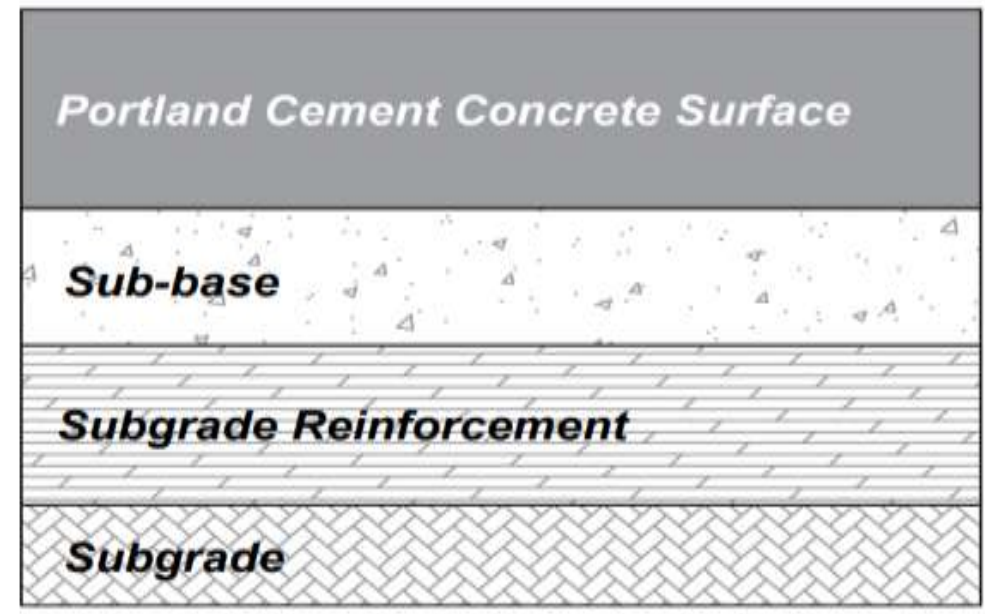

Source: Authors (2021).

The rigid floor is one in which the coating has a high level of stiffness when compared to the lower layers, which allows the capture of the stresses arising from loading. On the other hand, semi-rigid pavements are characterized by containing a base cemented by some binder with cementitious properties, such as a layer of cement soil covered by an asphalt layer (DNIT, 2019; Santos, 2019; Paixão, Cordeiro \& Correia, 2017).

The flexible pavement is directly associated with asphalt pavements, consisting of five layers that are configured in the asphalt surface layer (cladding), over the base, sub-base, and subgrade reinforcement layers, composed of granular materials, soils, or soil mixtures, but with the exclusion of cementing agents, according to figure 2 . It should be noted that the layers can be abolished due to some factors, such as traffic flow, the subgrade's carrying capacity, the stiffness, the thickness of the layers, and the environmental conditions (Bernucci et al., 2008).

Figure 2. Flexible type pavement structure.

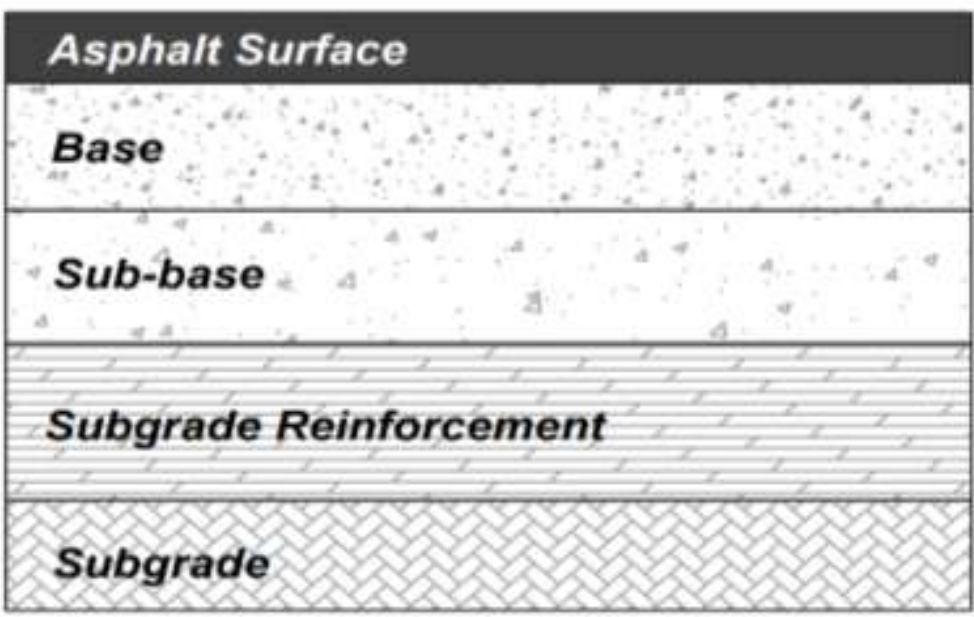

Source: Authors (2021). 
The definitions that cover the layers of a flexible floor are based on five layers, the first layer being the subgrade, which is the foundation ground, which is the support base for the floor. It is noteworthy that, when necessary, it is important to carry out the regularization of the subgrade, presenting the proper correction of faults in the final layer of the earthworks, but this regularization is not a layer (Balbo, 2007).

The subgrade reinforcement is the second layer, thick over the regularized subgrade to promote durability and qualities of the subgrade. The sub-base layer is between the regularized subgrade and the base layer, a complementary layer, and is indicated when it is not advisable to execute the base on the regularized subgrade. The base layer is executed to resist and distribute the traffic efforts to the subgrade and put an end to the coating layer, having the direct function of receiving the action of the vehicles' rolling, being intended to resist horizontal and vertical efforts, improving the bearing conditions and wear-resistant (Balbo, 2007)

Therefore, according to DNIT (2009), flexible pavements are characterized by all the layers subjected to significant elastic deformations under the applied load, thus, the load is divided into approximately equivalent portions between the layers.

\subsection{Pathologies associated with paving}

The DNIT (2006) asphalt pavement restoration manual points out that the maintenance of a highway must be a systematic and continuous process, which aims to maintain its function and guarantee economic traffic, comfort, and safety to users. Therefore, if the roads are not maintained, pathologies that are identified through a modification of the surface of the structure of the pavement prevail, changing its performance in a negative way (DNIT, 2006; Castro, 2009).

The DNIT 005/2003 - TER standard provides definitions regarding the types of pathologies found in asphalt coatings, such as cracks that are discontinuities in the pavement surface, responsible for smaller or larger openings, in different forms (DNIT, 2003).

Cracks are capillary width cracks in the lining, positioned longitudinally, transversely, or obliquely to the track axis, only noticeable to the naked eye from a distance of less than $1.50 \mathrm{~m}$. The possible causes of the appearance on the flexible pavement are due to the bad dosage of the asphalt, the excess of fines or filling material, and the compaction in excess or at an inappropriate time (DNIT, 2003; Barreto, 2016).

Cracks are cracks in the coating that are easily visible to the naked eye, with an opening greater than that of the fissure, and may appear in an isolated or interconnected form. The isolated cracks are divided into transverse, longitudinal, and retraction cracks, the first of which has a predominantly orthogonal direction to the track axis. When it shows an extension of up to $100 \mathrm{~cm}$, it is called short transverse crack, if the extension is greater than $100 \mathrm{~cm}$, it is called long transverse crack (DNIT, 2003; Barreto, 2016; Gomes, Da Silva, 2018).

The longitudinal crack is isolated and has a direction mostly parallel to the track axis. When it has an extension of up to $100 \mathrm{~cm}$, it is called a short longitudinal crack, and when the extension is greater than $100 \mathrm{~cm}$, it is called a long longitudinal crack. The shrinkage crack is isolated not attributed to the fatigue phenomena, but the thermal shrinkage phenomena, of the coating material or the rigid or semi-rigid base material underlying the cracked coating (DNIT, 2003; Barreto, 2016; Alves, Fernandes \& Bertequini, 2018).

The interlocking cracks are divided into two segments, the "Alligator Leather" crack, interlocking cracks without preferential directions, resembling the alligator leather appearance. These cracks may or may not present marked erosion at the edges. The "Block" crack composes the interconnected cracks and is configured as a set of interconnected cracks characterized by the configuration of blocks formed by well-defined sides, which may or may not show accentuated erosion at the edges (DNIT, 2003; Salomão, 2019). 
Sinking-type pathologies are permanent deformations characterized by depression of the pavement surface, accompanied or not by heaviness, and may present in the form of plastic sinking or consolidation. The type of plastic sinking is a sinking caused by the plastic creep of one or more layers of the pavement or subgrade, accompanied by elevation. When it occurs in an extension of up to $6 \mathrm{~m}$, it is called local plastic sinking; when the extension exceeds $6 \mathrm{~m}$ and is located along the wheel track, it is called the plastic sinking of the wheel track (DNIT, 2003; Balbo, 2007).

The consolidation sinking is caused by the differential consolidation of one or more layers of the pavement and subgrade without being accompanied by elevation. When it occurs over a length of up to $6 \mathrm{~m}$, it is called a local consolidation sink; when the extension exceeds $6 \mathrm{~m}$ and is located along the wheel track it is called the consolidation sinking of the wheel track (Adures et al., 2019).

Corrugation or corrugation is the deformation characterized by transverse corrugations or corrugations on the pavement surface. The slip is based on the displacement of the covering about the underlying layer of the pavement with the appearance of cracks in the shape of a half-moon. Exudation refers to the excess of bituminous binder on the pavement surface, caused by the migration of the binder through the coating (DNIT, 2003; Balbo, 2007).

Wear is defined as the effect of the progressive pulling out of the pavement aggregate, characterized by surface roughness of the coating and caused by tangential stresses caused by traffic. The pan or hole is the cavity that forms in the coating for several reasons (including the lack of adhesion between overlapping layers, causing the layers to peel off), reaching the lower layers of the floor, causing these layers to break down (Alves, Fernandes and Bertequini, 2018).

The patch is a pan filled with one or more layers of pavement in the operation called "plug-hole". The deep patch is one in which there is a replacement of the covering and, eventually, of one or lower layers of the pavement. Usually, it has a rectangular shape. Finally, the superficial patch is the correction, in a localized area, of the surface of the coating by applying a bituminous layer (Barbosa et al., 2018).

\section{Methodology}

The purpose of this study is to survey specific points of the existing degradations in the asphalt pavement of the city of Teófilo Otoni - Minas Gerais, Brazil, as shown in figure 3, and to indicate the possible causes and appropriate methodologies for the conservation and prevention of the appearance of pathologies, that is, the search for proposals that aim to solve these challenges. 
Figure 3. Map of the Brazilian territory identifying the state of Minas Gerais and the municipality of Teófilo Otoni, where the studied region is located.

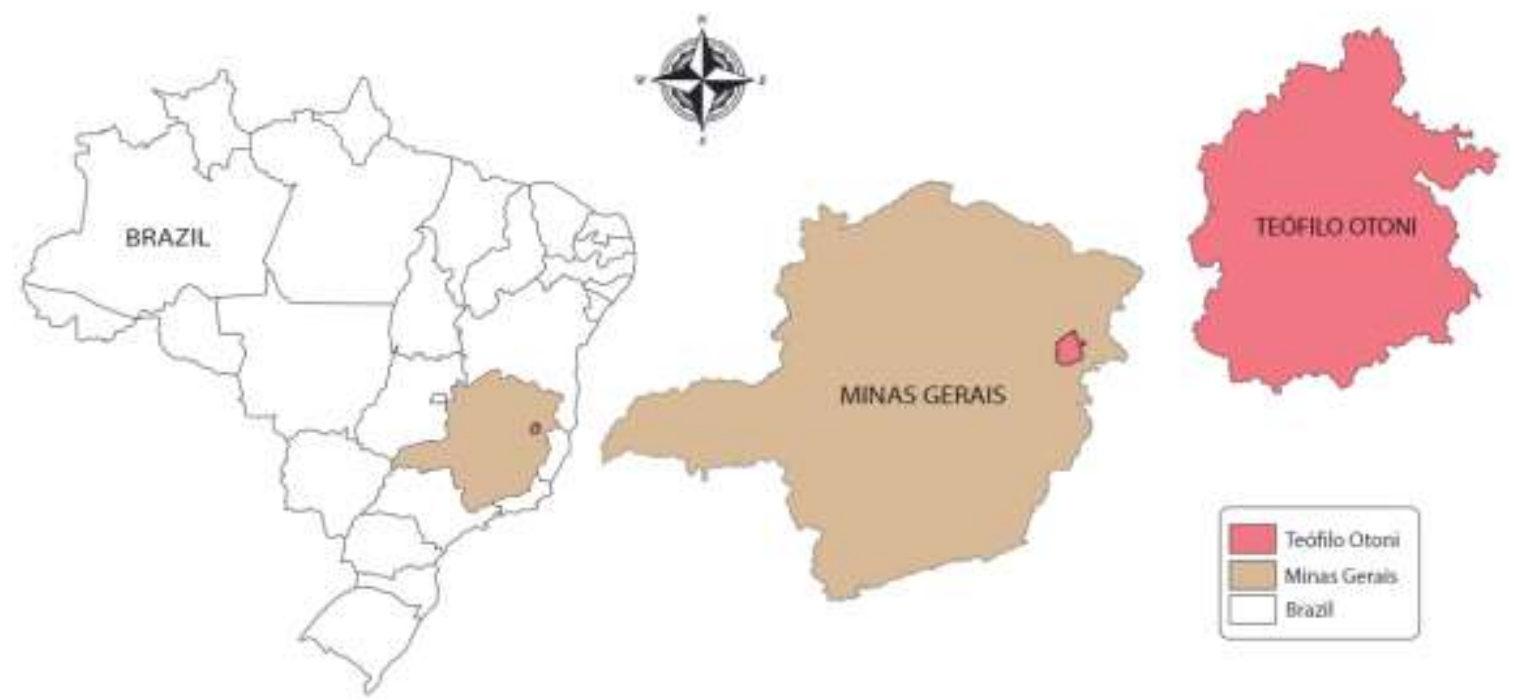

Source: Authors (2021).

In this way, the study is characterized as a case study, as it determines to create useful knowledge for the development of science without foreseen practical application, comprising universal truths and interests. Furthermore, the research can be classified as qualitative, considering the interpretation of the collected information and the allocation of solutions are basic in this process, not requiring the use of statistical methods and techniques; as well as descriptive and theoretical research, in which usual and pertinent situations of structural pathologies will be investigated in the bibliography available for comparison of data collected in the artwork under study (Pereira et al., 2018; Silva et al., 2021).

Observation techniques are very useful to reveal new perspectives on a problem. Qualitative methods are the ones in which the interpretation by the researcher with his opinions about the phenomenon under study is important. Data collection often occurs through interviews with opened questions, making it crucial in situations where there is no solid theoretical basis to guide data collection (Pereira et al., 2018; Ludke, 2013).

Classified as qualitative, the research used in this case study involves the interpretation of the information collected and the possible solutions, which are the basis of the qualitative research method. Usual and pertinent situations of pathologies in pavements were investigated with the available bibliography for comparison of the data collected in the study. The history of the occurrence of the pathologies that were treated in this work was shared by residents, who reported recurrences of municipal negligence regarding the maintenance and restoration of the pavement, when necessary, which contributed to its pathological evolution and degradation (Pereira et al., 2018; Silva et al., 2021).

Therefore, the analysis of the pathologies formed in the asphalt pavement of Teófilo Otoni will be in the city center, in the Ipiranga neighborhood, and on highway 116. This analysis aims to discuss their causes, establish a relationship between the causes, propose adequate methodologies for the conservation of pavements and preventive measures against the appearance of pathologies.

\subsection{Procedures adopted during study and analysis of results}

The survey of subsidies is the stage in which essential and sufficient information for a complete understanding of the pathological manifestations is organized. This information is obtained in two ways: site survey and analysis results. Thus, 
inspections were carried out on the roads, where pathological manifestations were identified, such as cracks, holes, also known as pans or depressions, longitudinal or transversal cracks, deformations, disintegration, exudation in blocks, edges, undermines. They were photographed and properly characterized. The technique and methodology for registering and organizing the subsidies collected are of fundamental importance for their use in formulating the diagnosis (Lichtenstein, 1986; Arivabene, 2015; Silva et al., 2021).

The process of understanding a pathological problem can be described as generating hypotheses or models and their respective tests. In other words, through certain fundamental data, the professional elaborates hypotheses for assessing the situation and compares the models to the general symptoms and to the knowledge he has about the pathology, according to Lichtenstein (1986). Following the reasoning, after collecting and interpreting the data, they will be analyzed in detail and the solution that has the best performance in terms of technical, economic, and environmental aspects will be proposed.

\section{Results and Discussion}

In figure 1, the main pathologies diagnosed in the studied pathways are presented. The research considered study routes and data that were collected through tactile-visual observation, which enabled the composition of the photographic collection of various points of the pavement covering, especially in places where some types of pathologies were observed.

In the central region of the city, cracks were found interconnected mainly in the longitudinal direction, parallel to the vehicle traffic, as shown in Figure 4. The cracks are located near Sorveteria Chiquinhos, (in Rua Epaminondas Otoni, 766 Centro, Teófilo Otoni - MG, 39800-013) and with reference to the Tristão da Cunha School (at Avenida Dr. Luís Boali Pôrto Salman, 1495 - Ipiranga, Teófilo Otoni - MG, 39801-000).

Figure 4. Longitudinal crack found in the central region of the city

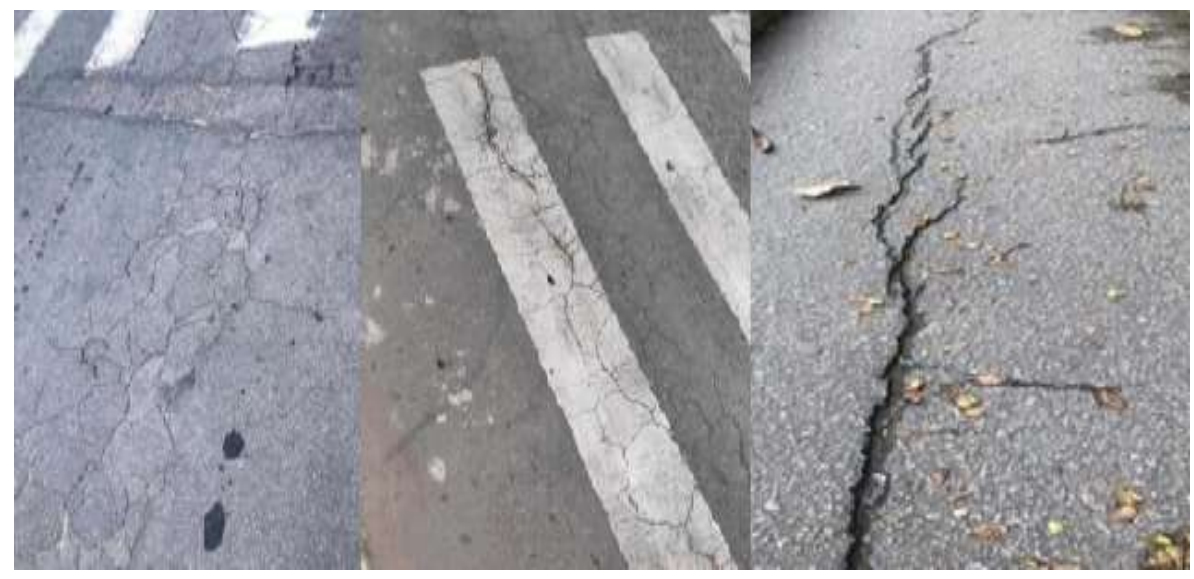

Source: Authors (2021).

The cause of the aforementioned pathology may be related to the contraction/expansion of the coating, poor execution of the longitudinal separation joint between the two traffic lanes, differential settlement, contraction of the asphalt layer, due to low temperatures, or the hardening of the asphalt. In this situation, palliative measures can solve the problem with the application of surface repairs, which can be done using a sealing layer to prevent water from entering and thus avoiding structural weakening (DNIT, 2010; Salomão et al., 2019).

Cracks interconnected without preferential directions, as shown in figure 5, found in the central region, may be caused by the collapse of the asphalt coating due to the repetition of traffic actions, the undersized or the poor quality of the structure of one of the pavement layers. , the low support capacity of the soil, the aging of the pavement, or the asphalt being hard or brittle, therefore, the same techniques used in longitudinal cracks are recommended (DNIT, 2010; Salomão et al., 2019). 
Research, Society and Development, v. 10, n. 7, e59710716928, 2021

(CC BY 4.0) | ISSN 2525-3409 | DOI: http://dx.doi.org/10.33448/rsd-v10i7.16928

To alleviate such causes, there are maintenance and restoration activities that are recommended by the DNIT Standard 154/2010 and are based on the improvement of drainage, replacement of sub-base, base and covering, resurfacing, or reconstruction of the application. It should be noted that the resurfacing and sealing layer, which works as superficial repairs, are efficient both for interlocking cracks of the block type and for the interconnected cracks of the alligator leather type, in this way, they have the same principle of repair for both pathologies (DNIT, 2010; Salomão et al., 2019).

Figure 5. Interlocking cracks without preferential directions

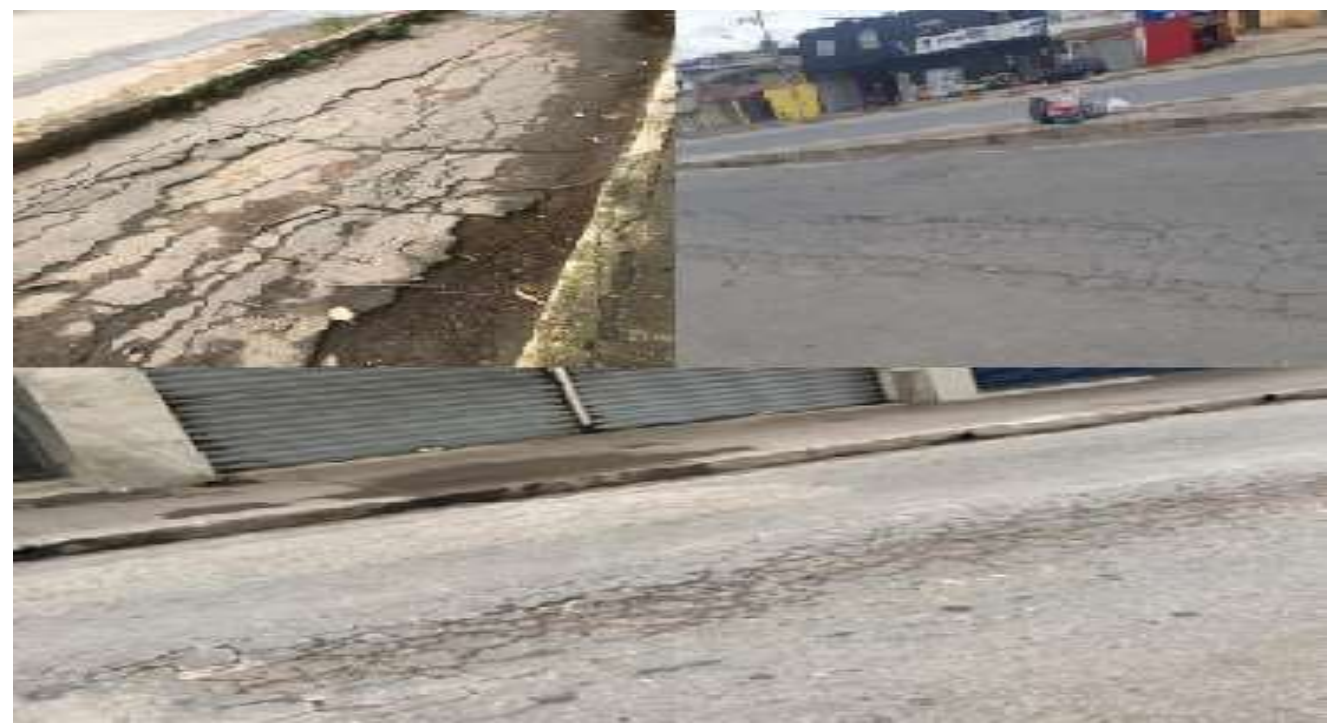

Source: Authors (2021).

The pans or holes, as shown in Figure 06, were found in a few sections. The cause may be due to the overloading of vehicles by the axle. The recovery of this type of pathology can be accomplished through patches when well executed, however, this type of recovery is only recommended if the base, sub-base, and sub-grade has not yet been reached. If the hole is deeper, a straight cut should be made in the coating, then priming to seal the cracks and then applying a new asphalt pavement (DNIT, 2010; Salomão et al., 2019).

Figure 6. Pans or holes identified

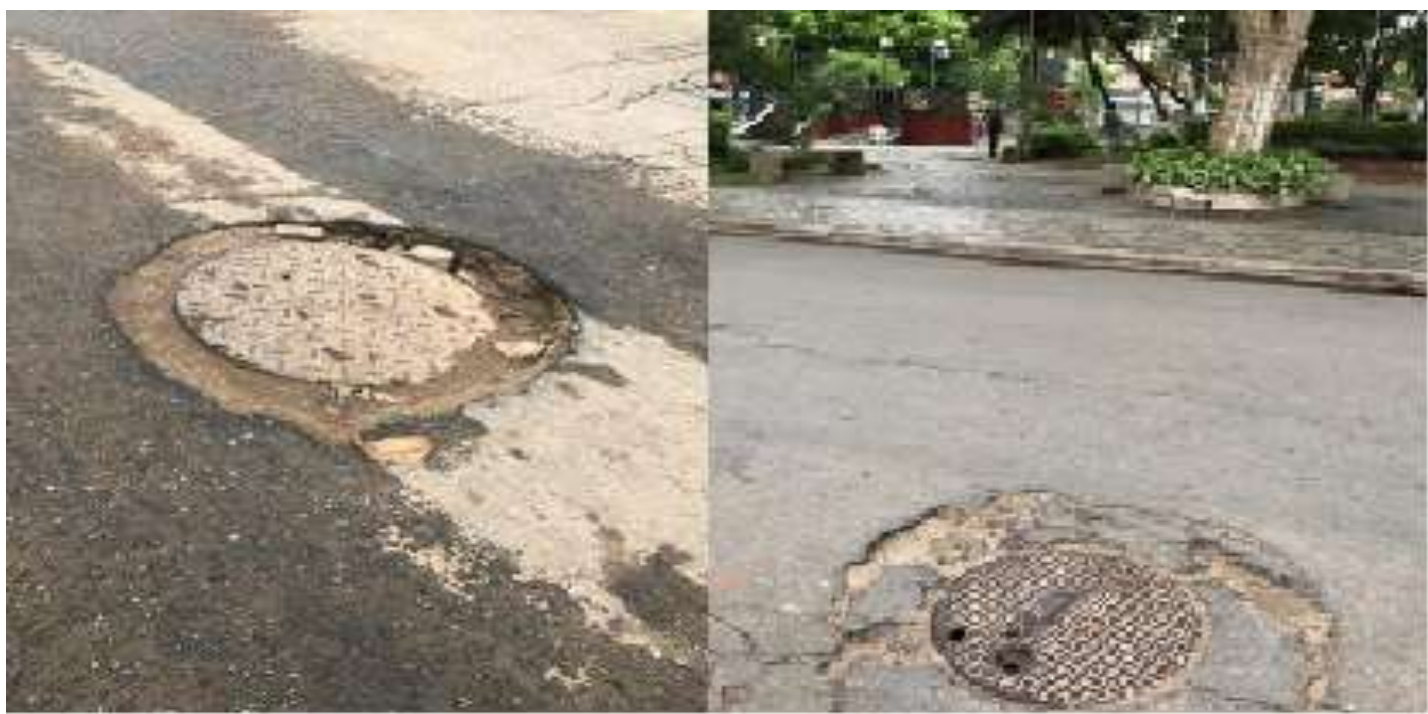

Source: Authors (2021). 


\section{Conclusion}

Through the photographic survey, it was possible to carry out the visual verification and thus diagnose the main pathologies found in the stretches. It was found that the largest amounts of pathology were cracks, in addition to pots (holes) and side wear. These defects end up impairing the traffic of the road, since to maintain safety it is necessary to reduce the speed of the vehicles, mainly to avoid the most critical points.

It can be concluded that the damage presented is due to the poor execution of the pavement and the lack of maintenance of its quality. Therefore, one of the proposed correction measures for the presented pathologies would be the use of the micro-coating method for the cracks and crevices and the execution of patches for the pans. However, the latter must be done properly, with the recovery of the pavement layers first and a straight cut of the covering to avoid the generation of future damage in the same place. It is worth mentioning the importance of the proper execution of all paving steps, using appropriate techniques and materials, from compacting to coating, as they are all essential to avoid the appearance of pathologies.

It is also recommended that the municipal management of Teófilo Otoni periodically carry out corrective and preventive maintenance actions on the city's paved roads. It is hoped that the present case study will become a reference for future work, to provide greater inspection of all execution processes, since it is of fundamental importance for the quality control of the materials used, possibly constituting a factor determinant for the degradation of the studied pavement structure.

Thus, it is recommended that in future studies a survey of the quality of the materials used in the paving of the municipality be carried out, as well as an analysis of the process of pavement execution and correction of pathologies, according to the normative recommendations of bodies such as DNIT, as such results can help to definitively solve the problems presented here.

\section{References}

Adures, L. A. K. et al. (2019). Estudo de caso de patologias em pavimento flexível em trecho da rodovia MS-162. Dourados, MS.

Alvarez, S. P., Rodgher, F. S. (2018). Patologias e manutenção no pavimento asfáltico no município de Bocaina/SP. Revista Científica Semana Acadêmica. Volume 1. Fortaleza, CE.

Alves, M. T. O., Fernandes, R. E. C., \& Bertequini, A. B. T. (2018). Patologias em pavimento flexível. Araçatuba, SP.

Arivabene, A. C. (2015). Patologia em estruturas de concreto armado: estudo de caso. Especialize Online IPOG. Volume 1, nº 10, pp.5-6. Goiânia, GO. https://fdocumentos.tips/document/patologias-em-estruturas-de-concreto-armado-estudo-de-em-estruturas-de-concreto.html.

Balbo, J. T. (2007). Pavimentação Asfáltica: materiais, projeto e restauração. São Paulo: Oficina de textos.

Barbosa, L. C. et al. (2018). Estudo de patologias em pavimento asfáltico no trecho dique estrada na cidade de Maceió-AL. Maceió, AL.

Barreto, S. S. (2016). Estudo e abordagem da origem e desenvolvimento das patologias em pavimento. Revista Saber Acadêmico. Volume 21.2016. Presidente Prudente, SP.

Bernucci, L. B. et al. (2008). Pavimentação asfáltica: formação básica para engenheiros. Rio de Janeiro, RJ.

Castro, P. C. G. (2009). Defeito dos pavimentos asfálticos e suas causas. Rio Grande do Sul, RS.

CNT - Confederação Nacional de Transportes. (2018). Somente 12,4\% da malha rodoviária brasileira é pavimentada.

Costa, M.R., Batista, T.O. (2019). Um estudo sobre patologias em pavimento flexível na cidade de Manhuaçu/MG. Seminário Científico do UNIFACIG. Volume 5. Manhuaçu, MG.

Czrnhak, A. C., Huber, N. L., \& Dusi, L. (2019). Estudo de patologias de pavimentos flexíveis na cidade de Caçador/SC. Ignis: Periódico Científico de Arquitetura e Urbanismo, Engenharias e Tecnologia da Informação. Volume 8, nº 1, pp. 83-95. Caçador, SC.

Da Silva, A. L., (2019). Estudo comparativo entre pavimento rígido e pavimento flexível.

Daibert, J. D., Daibert, J. A., Daibert, T. J. Z. (2015). Rodovias: Planejamento, Execução e Manutenção. Editora Érica.

DNIT - Departamento Nacional de Infraestrutura e Transporte. (2003). 005/2003 - TER - Defeitos nos pavimentos flexíveis e semi-rígidos Terminologia. Rio de Janeiro, RJ. 
Research, Society and Development, v. 10, n. 7, e59710716928, 2021

(CC BY 4.0) | ISSN 2525-3409 | DOI: http://dx.doi.org/10.33448/rsd-v10i7.16928

DNIT - Departamento Nacional de Infraestrutura e Transporte. (2006). IPR - 720 - Manual de restauração de pavimentos asfálticos. $2^{\mathrm{a}}$ ed. Rio de Janeiro, RJ.

DNIT - Departamento Nacional de Infraestrutura e Transporte. (2010). 154/2010: Recuperação de Defeitos em Pavimentos Asfálticos. Rio de Janeiro, RJ.

Flek, C. M. (2017). Diagnóstico de patologias encontradas na rodovia BR-050 entre Araguari e Uberlândia. Revista Construindo. Volume 9 , $\mathrm{n}^{\circ} 3$. Belo Horizonte, MG.

Gomes, F. A. V., Da Silva, J. V. (2018). Terraplanagem e a aplicação do concreto betuminoso usinado a quente (CBUQ) para pavimentação em vias urbanas. Goianésia, GO.

Gomes, M.L.B., Júnior, F.V.S. (2019). Patologia em pavimentos flexíveis: estudo de caso para o estacionamento do ITPAC Porto. Revista Inventionis. Volume 1, na 1, pp.1-11. Aracaju, SE.

Lichtenstein, N. B. (1986). Patologia das Construções. Escola Politécnica da Universidade de São Paulo - EPUSP. Boletim Técnico, nº 06. São Paulo, SP.

Lüdke, M. A. (2013). MEDA de. Pesquisa em educação: abordagens qualitativas. São Paulo: E.P.U.

Marinho, M. (2021). Rodovias, Serviços e Qualidade: uma proposta de avaliação. Editora Dialética.

Paixão, M. P. Cordeiro, C. C. C., \& Correia, M. C. N. (2017). Pavimentos semirrígidos: prevenção e tratamento da reflexão de trincas. Seminário Estudantil de Produção Acadêmica. Volume 16. Salvador, BA.

Reis, S. F. N. (2009). Análise Estrutural de Pavimentos Rodoviários. Aplicação a um Pavimento Reforçado com Malha de Aço. Lisboa, PT.

Ribeiro, T. P. (2017). Estudo descritivo das principais patologias em pavimento flexível. Revista Científica Multidisciplinar Núcleo do Conhecimento. Volume $1,4^{\mathrm{a}}$ ed, pp. 733-754. São Paulo, SP.

Rosa, K. K. B. et al. (2016). Diagnóstico e procedimento de recuperação das patologias apresentadas na pavimentação asfáltica de Palmas/TO. Revista Integralização Universitária. Volume 11, nº 15, pp. 44-58. Palmas, TO.

Salomão, P. E. A. et al. (2019). A importância dos serviços de conservação em estradas pavimentadas. Revista Pesquisa, Sociedade e Desenvolvimento, [S. 1.], v. 8, n. 8, pág. $1688-1189$

Santos, F. C. S. (2019). Pavimentação: análise comparativa entre pavimento rígido e o pavimento flexível. Anápolis, GO.

Silva, H. T., Guimarães, L. S., Tolentino Júnior, D. S., Campos, A. S., Frisso, A. L., Costa, A. S. V., Cabral, S. C. \& Freitas, L. F. (2021). Restoration proposal for correction of pathologies in concrete bridge - case study in the city of Teófilo Otoni, Brazil. Research, Society and Development, 10(6), e21810615767. Disponível em: https://rsdjournal.org/index.php/rsd/article/view/15767. Acesso em: 22 jun. 2021.

Zuchetti, P. A. B. (2015). Patologias da construção civil: investigação patológica em edifício corporativo de administração pública no Vale do Taquari/RS. Lajeado, RS. 